\title{
ADDITÍV GYÁRTÁSTECHNOLÓGIÁVAL, VIRTUÁLISAN TERVEZETT EGYÉNI IMPLANTÁTUMOK NUMERIKUS ANALÍZISE
}

\section{NUMERICAL ANALYSIS OF ADDITIVELY MANUFACTURED, INDIVIDUAL TITANIUM IMPLANTS DESIGNED IN A VIRTUAL ENVIRONMENT}

\author{
Kulcsár Klaudia, ${ }^{1}$ Kónya János ${ }^{2}$ \\ ${ }^{1}$ Dent-Art-Technik Kft. Győr, Magyarország, kulcsar.klaudia@dentarttechnik.hu \\ ${ }^{2}$ Dent-Art-Technik Kft.Györ, Magyarország, labor@dentarttechnik.hu
}

\begin{abstract}
The aim of this study is the design, manufacture, and development of a metallic rehabilitation device (titanium frame structure) that is created with a printing process. Product design is inspired by the Computed Tomography (CT) based reconstruction method, during which a metallic frame structure is designed that perfectly fits the retrieved bone surface. The internal structure of the designed metallic frames is a statically analysed three-dimensional construct which makes it possible to create individual product types. Constructs with different structure are checked by finite element analysis. Our goal is to establish a standardised manufacturing process, in which specific mechanical stressing can be carried out and optimal product type chosen, depending on different cases. At the end of this study, our solution of choice is demonstrated with surgical pictures.
\end{abstract}

Keywords: additive manufacturing, virtual design, implant, subperiosteal implant, numerical analysis.

\section{Összefoglalás}

Tanulmány tárgya egy olyan fémből (titán) készült rehabilitációs eszköz (háló) tervezése, gyártása és fejlesztése, amelyet nyomatásos eljárással hozunk létre. A termék tervezése Computed Tomography (computertomográfia, CT) alapú rekonstrukciós módszeren alapszik, ahol a kinyert csontfelülethez pontosan illeszkedő fémhálót tervezünk. A megtervezett fémhálók belső szerkezete statikailag is méretezett, térdimenzionált struktúra, amely lehetővé teszi, hogy egyedi gyártmánytípusokat hozzunk létre. A különböző szerkezetű struktúrákat végeselem-analízis segítségével ellenőrizzük. Célunk, hogy egy standardizált gyártást hozzunk létre, ahol az esetektől függően, specifikusan méretezhetjük és választhatjuk ki az optimális gyártmánytípust. A tanulmány végén az általunk kiválasztott megoldást mutatjuk be műtéti képekkel.

Kulcsszavak: additív gyártástechnológia, virtuális tervezés, implantátum, subperiostealis implantátum, numerikus analízis.

\section{Bevezetés}

Az elmúlt években egy teljesen fogatlan állkapocs implantátummal történő kezelése rutinszerűvé vált. A teljesen fogatlan pácienseknél, akiknek a hagyományos protézis használata gondot jelent, jelentős előny lehet az implantátum alkalmazása [1].
Walton és munkatársai összehasonlították a betegek elégedettségét az állkapocsprotézis használatáról, melyek egy vagy két implantátumot tartalmaztak 86 résztvevőnél, egy éven keresztül. Ebben a találomszerűen kiválasztott klinikai vizsgálatban a kutatók alacsonyabb költséget értek el és a kezelési idő is csökkent, hasonló elégedettség- 
gel és kezelési idővel, mint az egyszerű középvonalú implantátum esetén [2]. Egyes szerzők azonban nem várt módon magas hibát jelentettek az egyrészes implantátumok esetében az azonnali terhelést követően [3]. Más kutatók véleménye szerint az állkapocsra a fogazatot 3 vagy 4 implantátum segítségével kell rögzíteni. Elméletileg a 3 vagy 4 implantátum alkalmazása az implantátumok között egyenes vonalú kapcsolat helyett merev kapcsolatot eredményez. A három implantátummal támogatott fogsor, a legelőnyösebb beültetett implantátum indirekt retenciót biztosít a fogsor számára. Ezért egyes szerzők azt ajánlják, hogy az orvosok 3 vagy 4 implantátumot alkalmazzanak azokban a helyzetekben, ahol megnövelt retenciót igényel vagy kiemelkedő állnyelvcsonti gerincet [4]. Meijer és munkatársai nem találtak egyértelmű különbséget a klinikai és röntgeneredmények esetében a két implantátummal támogatott, valamint 4 implantátummal támogatott mandibulafogsor eredményei között egy 10 éves értékelési időszak alatt [5]. A retenció mellett fontos az is, hogy az implantátumokat ne érje túlzott terhelés [6]. A természetes fogaknál a fog körüli ínszalag közbenső párnaként szolgál az okklúziós terhelésnél. Az osszeointegrációs fogászati implantátumok esetében az okklúziós terhelés közvetlenül a környező csontokba kerül. Túlterhelés esetén az implantátumok körüli csontban nagy deformáció fordul elő. Ha kóros túlterhelés következik be, akkor a feszültség- és az alakváltozás-gradiensek meghaladják a csont élettani határait, mikrotörést okozhatnak a csontimplantátum felületén, mely implantátum töréshez, az implantátumrendszer komponenseinek lazulásához és nemkívánatos csontfelszívódáshoz vezethetnek [7, 8]. Felismerve a túlterhelés által okozott károkat, külön figyelmet fordítanak az implantátum körüli csontban fellépő feszültségre és alakváltozásra. A háromdimenziós végeselem-elemzés pontos és megfelelő közelítésnek tekinthető a feszültség és az alakváltozás eloszlásának vizsgálata során, és számos előnnyel jár a klinikai szituációk összetettségének szimulálásában [9].

A csontban implantátum által rögzített protézissel rendelkező páciensek közel 56\%-ánál periimplantitis alakul ki, mely végül végleges elvesztéshez vezet [10]. A periimplantitis sok okozója közül a legtöbb klinikailag nem szabályozható [11]. A maxilláris csontvesztés implantátumvesztéssel kombinálva vagy a használhatatlanságból eredő sorvadás nagy kihívást jelent. Jelenlegi megoldások közé sorolható az „all-on-4” megoldás, ha elegendő csonttömeg áll a rendelkezésre, a „quad-zy- goma” vagy másképpen a járomcsont-implantátumok, és a csontpótlás, majd ezt követő (ismételt) implantációval [12, 13].

A CADCAM-rendszer fejlődése precíz műtét előtti tervezést és páciensre szabott implantátum tervezését teszi lehetővé [14, 15]. Az egyedi implantátumok tervezési folyamata a következő: 2D CT képek 3D DICOM-fájlokká alakítása; 3D software egyedi készítésű implantátum tervezésre; 3D sztereolitográfia (STL) minta nyomtatása; 3D titán implantátum nyomtatása 3D nyomtatóval [16].

$\mathrm{Az}$ additív gyártás (Additive Manufacturing, AM), amelyet általánosan 3D nyomtatásnak is neveznek, olyan folyamatok egy csoportja, melyek háromdimenziós (3D) modelladatokból hoznak létre testeket, az objektumoknak a felépítése rétegről rétegre történik [17]. Az utóbbi években számos tanulmány készült az AM-technika alkalmazásáról a szöveti sebészetben [18-21]. Csontot és a szívhez alkalmazott szöveteket sikeresen gyártottak [22]. Az ASTM F2792-12a szabvány szerint mind a szelektív lézerolvasztás (SLM), mind az elektronsugaras olvasztás (EBM) porágyfúziós technológiának minősül, ahol a hőenergia szelektív módon biztosítja a porágy régiói olvasztást [17].

A titán és ötvözetei széles körben használatosak fogászati és ortopédiai fémimplantátumoknál, mivel képesek a csontba beépülni [23-25]. A titán és a titán-alumínium-vanádium (Ti6Al4V) a felületükön természetesen előforduló passzív oxidréteget tartalmaz, amely biológiailag előnyös és ellenáll a korróziónak, mindeközben továbbra is erős mechanikai tulajdonságokkal és nagy szilárdság/tömeg aránnyal rendelkezik [26]. Az implantátum felületi érdessége egy olyan tényező, amelyről kimutatták, hogy az élő szervezetben (in vitro) elősegíti az osseointegráció folyamatát [27, 28]. Bár a fogászati implantátumok sikerét az egészséges páciensek (kezelés alatt lévő emberek) több mint 95\%-ában érik el, bizonyos kockázati tényezők még mindig gátolják az osszeointegrációt. A cukorbetegek és a dohányzók osszeointegrációs rátája drasztikusan csökken [29]. Az endostealis (csontba ültetett) implantátumok viselkedése numerikus módszerekkel vizsgálhatók. Az utóbbi időben egyre gyakrabban alkalmazzák a végeselem módszerét [30] a feszültség és alakváltozás eloszlásának előrejelzésére az implantátum körüli régiókban, az implantátum és a protézis hatásának vizsgálatára [31-34], a terhelések nagysága és iránya, [35, 36] és a csont mechanikai tulajdonságai [37, 38], valamint kü- 
lönböző klinikai forgatókönyv modellezésére [39, 40].

A csontok mechanikai terhelésekre gyakorolt biológiai reakciója befolyásolja az implantátum élettartamát [41]. Mivel a terhelés áthatol a csontba a protézisen és az implantátumon keresztül, ezért a protézis gondos tervezést és végrehajtást igényel, melynek egyik fontos tényezője a megfelelő feszültségeloszlás a csontban [42]. Az utóbbi időben főként a kétdimenziós (2D) és a háromdimenziós (3D) végeselemes elemzések (FEA) segítségével vizsgálják a csontok korrelációját az implantátum által támogatott protézisekkel. Az elemzések pontosságát összehasonlító tanulmányok kimutatták, hogy ha részletes feszültséginformációkra van szüksége, akkor a 3D modellezésre lesz szükség [43].

Az implantátum meghibásodásának leggyakoribb okai a gyenge szájápolás és a biomechanikai tényezők [44]. Az implantátumoknak meg kell felelniük az intraorális erők által kiváltott feszültségnek. A megnövekedett vagy rendellenes terhelés, valamint élettani terhelés mellett fellépő kifáradás az implantátumrendszer összetevőinek töréséhez vezethet [45].

A végeselemes (FE) elemzést széles körben alkalmazták az implantátum körüli csontok feszültségének kiértékelésére a fogtalan álkapocsban [46]. Meijer és munkatársai egy háromdimenziós FE-modellt alkalmaztak, amely az állkapocs belső erőkifejtését ábrázolja [47].

A végeselemmódszer (FEM) egy sor számítási eljárást tartalmaz a feszültség és az alakváltozás kiszámításához. Az ilyen strukturális analízis lehetővé teszi a külső erő, nyomás, hőmérséklet-változás és egyéb tényezők által kiváltott feszültség és alakváltozás meghatározását [48].

\section{Anyagok és módszerek}

\subsection{Alkalmazott titánötvözet jellemzői}

A titán és ötvözetei kiváló korrózióállósággal és biológiai kompatibilitással rendelkeznek. A protézisek, implantátumok, valamint orvosi eszközök legelterjedtebb titánötvözete a Ti-6Al-4V, mely irányadó anyaga a csontpótlásnak. Az LMF (Laser Metal Fusion) technológiával legyártandó minták és modellek alapanyaga a Grade 23-as Ti-6Al-4V ötvözet. Az alapanyagpor gyártója a runcomi (Egyesült Királyság) székhelyű LPW Technology Ltd. Az alapanyagra jellemző átlagos porszemcseméret 10-45 $\mu \mathrm{m}$ nagyságrend közt változik. Az odaicót elkerülendő, a poralapanyagra argon atmoszférában kerül csomagolásra és tárolásra egyaránt. Tömegszázalékos összetétele látható az 1. táblázatban.

Legfontosabb érvek a titán mellett például a föld 0,63\%-át adó, 9. leggyakrabban előforduló, kis fajsúlyú elem, antiallergén. Az implantológiában a felületén létrejövő oxidréteghez kötődik a humán csontszövet. Kis fajsúlya miatt jelentősen csökkenti a pótlások súlyát, növeli komfortját, valamint fémlemezként nem okoz mellékízt a szájüregben. Allergiás problémáról még az aranynál is is ritkábban ír a szakirodalom.

1. táblázat. Ti-6Al-4V tömegszázalékos összetevője

\begin{tabular}{|c|c|c|c|}
\hline \multirow{3}{*}{ Örvözet } & \multicolumn{3}{|c|}{ Kémiai összetétel $\mathbf{~ m} / \mathbf{m}$ \% } \\
\cline { 2 - 4 } & Ötv. & $\mathbf{m i n}$ & $\mathbf{m a x}$ \\
\hline \multirow{7}{*}{$\mathrm{Al}$} & 5,5 & 6,5 \\
\cline { 2 - 4 } & $\mathrm{C}$ & & 0,08 \\
\cline { 2 - 4 } & $\mathrm{Fe}$ & & 0,25 \\
\cline { 2 - 4 } & $\mathrm{H}$ & & 0,0125 \\
\cline { 2 - 4 } & $\mathrm{N}$ & & 0,03 \\
\cline { 2 - 4 } & $\mathrm{O}$ & & 0,13 \\
\cline { 2 - 4 } & egyéb külön & & 0,1 \\
\cline { 2 - 4 } & egyéb össze & & 0,4 \\
\cline { 2 - 4 } & $\mathrm{Ti}$ & reszt & reszt \\
\cline { 2 - 4 } & $\mathrm{V}$ & 3,5 & 4,5 \\
\hline
\end{tabular}

\subsection{Additív gyártástechnológia}

A 3D nyomtatás additív gyártási eljárás, amely vékony rétegek lerakásával/felhordásával készít tárgyakat. 3D nyomtatással háromdimenziós tárgyak hozhatók létre, melyhez térbeli digitális modelleket használunk fel. Az additiv gyártási eljárást a digitális modell készítése előzi meg (STL) (háromszögelt felületállomány). A 3D nyomtató saját technológiája az LMF. Az LMF-technológiát komplex fémalkatrészek fémporból történő előállítására alkalmazzák. Az LMF-eljárással komplex belső szerkezetek hozhatók létre. A lézer a fémport megolvasztva rétegről rétegre építi fel a kívánt térfogatot. Intelligens szoftver határozza meg a szilárdtestlézerek ideális pásztázási útvonalát. A nyomtatott minták és modellek gyártása egy SISMA Mysint 100, lézersugaras olvasztáson alapuló 3D nyomtató berendezésben történt. A nyomtató működés közben látható az 1. ábrán.

A nyomtatott minták és modellek 3D nyomtatással történő legyártását követően a minták és modellek az építő platformról eltávolításra kerülnek. 
Az 2. ábrán látható a nyomtatást követően a minta, ahogy kikerül a 3D nyomtatóból.

\section{Egyéni titánimplantátum}

Az egyéni implantátum, titánháló megvalósításával olyan lehetőségeket kínálunk a rehabilitáció területén, amely akár életkörülményeket javít. A daganatos, illetve egyéb csonteffektusokkal rendelkező páciensek esetében oly nagymértékű lehet az eltávolítandó csont kiterjedése, hogy a lágy szöveteknek már nem képes a megfelelő megtámasztást nyújtani a koponyacsont. Az ilyen nagy áthidalásokat fémhálós pótlásokkal lehetséges megoldani, amelyet a hagyományos megoldásoktól eltérően speciális fémhálóval kívánunk megoldani.

A termék tervezése CT-alapú rekonstrukciós módszeren alapszik, ahol a kinyert, valós csontfelülethez pontosan illeszkedő fémháló készítése a feladat. Nem csupán a fémháló geometriáját tervezzük meg, hanem az anyag belső szerkezeti struktúráját is. Az így megtervezett fémhálós belső szerkezet statikailag, illetve dinamikailag méretezett, térdimenzionált struktúra, amely lehetővé teszi, hogy egyedi gyártmánytípusokat hozzunk létre.

A térszerkezetes egyedi gyártású titánháló gyártási folyamata három fő egységre választható szét.

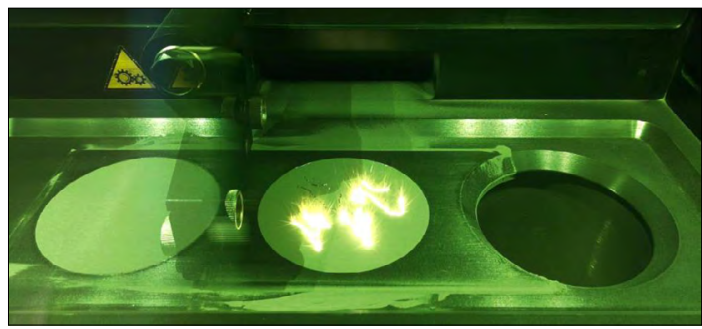

1. ábra. SISMA Mysint nyomtató müködés közben

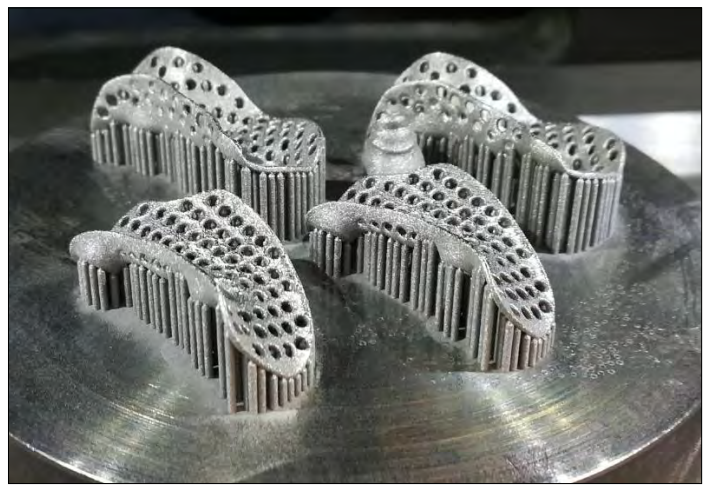

2. ábra. $3 D$ nyomtatott minták
- előkészítés;

- 3D nyomtatás;

- utómunkálatok.

$\mathrm{Az}$ általunk kidolgozott eljárásban először egy virtuális tervezés történik. Ebben a fázisban képesek vagyunk előállítani az érintett csontterület pontos, háromdimenziós képét az alkalmazott képalkotó eljárásoknak és feldolgozó szoftvereknek köszönhetően. A tervezés első fázisa a CT feldolgozása, majd ebből a csontfelület generálása, melynek folyamata látható a 3. ábrán.

A CT-felvételből STL-fájlt generálunk, ezt követően a kapott STL-fájl hibái, majd az ideális fogmű javítását végezzük el. Az ideális fogmű alapján rögzítési/áttörési pontok meghatározása következik, ez a folyamat látható a 4. ábrán.

Ezt követi a fémháló megtervezése, amely még mindig virtuálisan történik. A folyamat első lépése a korábban idealizált fogmű figyelembevételével a titánháló határvonalának meghatározása, majd a háló paramétereinek (vastagság, struktúra kialakítása) megadása történik. A lépések az 5. ábrán láthatók.

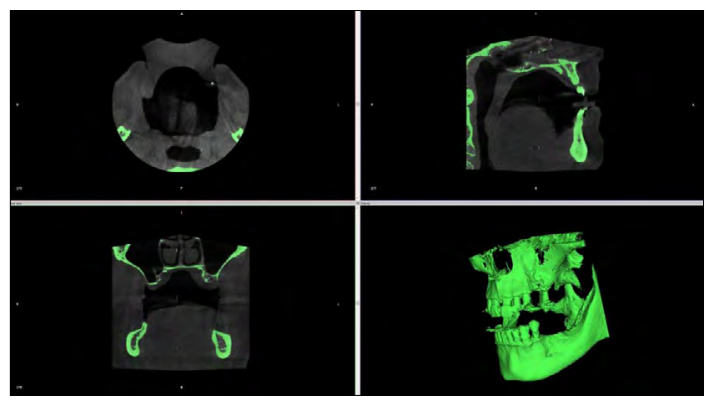

3. ábra. CT-feldolgozás és csontfelület generálása

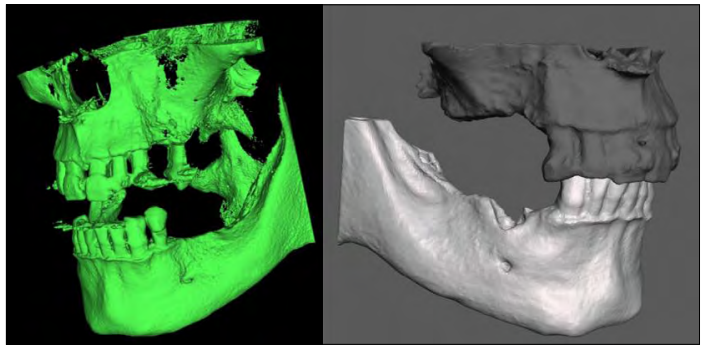

4. ábra. STL-file generálása és ideális fogmü tervezése. a: CT-modell, b: STL-modell

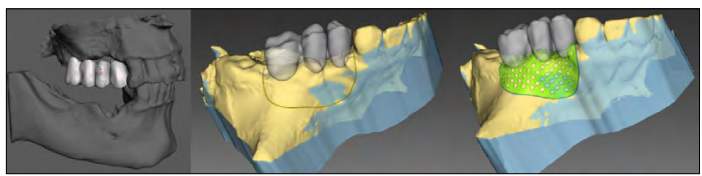

5. ábra. Titánháló határvonalának és paramétereinek meghatározása 
Szükség esetén a csontfelszín és az implantátum előállítása is lehetséges 3D nyomtatási technológiával, amely közvetlen vizualizációt biztosít, és a mütét során felmerülő esetleges nehézségekre is időben felhívja a figyelmet, ez látható a 6. ábrán.

Ezt követően kerülhet sor a titánháló mütéti behelyezésére, valamint a számítógépes tervezésnek megfelelően előre elkészített furatokon keresztül a csavaros rögzítésre.

\section{Egyéni titánimplantátum numerikus analízise}

A subperiosstealis implantátumot, vagy másképpen a corticalis megtámasztású egyéni implantátumot, ahogy ma hívjuk, először 1936-ban fejlesztették ki, ebben az időben az implantátum alapanyaga vitallium és valamilyen széntartalmú acél volt [2, 8]. A győri székhelyü Dent-Art-Technik Kft. fejlesztette ki titán alapanyagból, amiért 2014-ben Magyar Nagydíj elismerésben részesítették.

Különböző kialakításokat vizsgáltunk meg a tanulmány során. Az implantátum kialakítása többféle lehet, az irodalmakban is fellelhető jó pár megoldás. Jelen tanulmányban főként az implantátum térdimenzionált struktúra mértékét, valamint az implantátum peremének zártságát vizsgáltuk. A 7. ábrán láthatóak a főbb kialakítások.

A 2. táblázat tartalmazza a strukturáltság nagyságát, a zártságot és a vastagságot. Természetesen

2. táblázat. Vizsgált titánhálók adatai, értékei

\begin{tabular}{|l|c|c|}
\hline \multicolumn{1}{|c|}{ Titánháló } & $\begin{array}{c}\text { Feszültség } \\
\text { [Mpa] }\end{array}$ & $\begin{array}{c}\text { Alakváltozás } \\
\text { [mm] }\end{array}$ \\
\hline $\begin{array}{l}\text { Zárt szél, 1,5 mm } \\
\text { strukturáltság }\end{array}$ & 34,683 & 0,0043 \\
\hline $\begin{array}{l}\text { Nem zárt szél, 1,5 mm } \\
\text { strukturáltság }\end{array}$ & 61,105 & 0,0427 \\
\hline $\begin{array}{l}\text { Zárt szél, 1 mm struk- } \\
\text { turáltság }\end{array}$ & 183,122 & 0,1243 \\
\hline
\end{tabular}

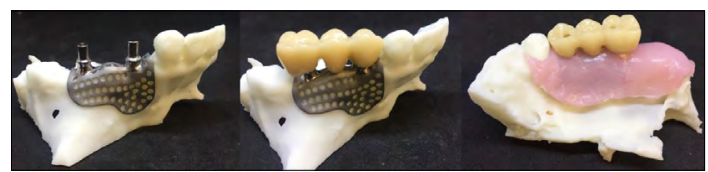

6. ábra. 3D nyomtatással elöállított vizualizáció

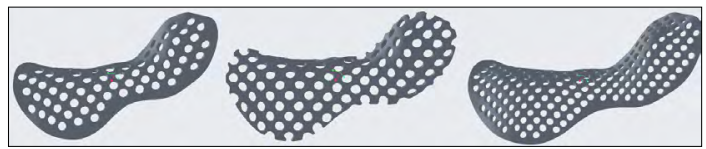

7. ábra. A vizsgált titánhálók kialakításai több vizsgálatot végeztünk, de azok eredményei nem voltak relevánsak. A táblázatban a vizsgált titánhálók a 7. ábrán feltüntetett kialakítások szerint, a táblázat sorának sorrendje megegyezik az ábrán lévő sorrenddel. Első sorban található a 0,65 mm vastagságú lemez, zárt széllel és a belső strukturáltság értéke 1,5 mm, a második sor tartalmazza a 0,65 mm vastagságú, bezáratlan szélü és 1,5 mm-es strukturáltságú lemezt. A harmadik sor tartalmazza a 0,65 mm vastagságú, zárt szélü és $1 \mathrm{~mm}$-es strukturáltságú lemez adatait. Véges elemes futtatásokkal meghatározott feszültségértékek, valamint alakváltozások értékeit tüntettük fel a táblázat 2-3. oszlopaiban.

Először bemutatjuk azt a kialakítást, mely a legjobb eredményt hozta. A 8. ábrán látható a rágóerő iránya, távolsága a titánháló felületétől $11 \mathrm{~mm}$. Az ábrán látható még a persely, melyet belehegesztenek. A hegesztés anyagtudományi vizsgálatával is foglalkoztunk, melyet az Additív technológiával készülő egyéni implantátumok lézeres mikrohegesztésének vizsgálata című tanulmányunkban [49] tárgyaltunk.

A továbbiakban bemutatjuk annak a modellnek a végeselemanalízis-eredményét, melynél a legjobb eredményt kaptuk. A 9. ábrán látható a $0,65 \mathrm{~mm}$ vastagságú lemez, zárt széllel és a belső strukturáltság értéke 1,5 mm-es lemez. Az ábrán észrevehető, hogy a legnagyobb feszültség ott ébred, ahol az abutment, másképpen a felépítmény, valamint a persely lesz behelyezve, amire majd a

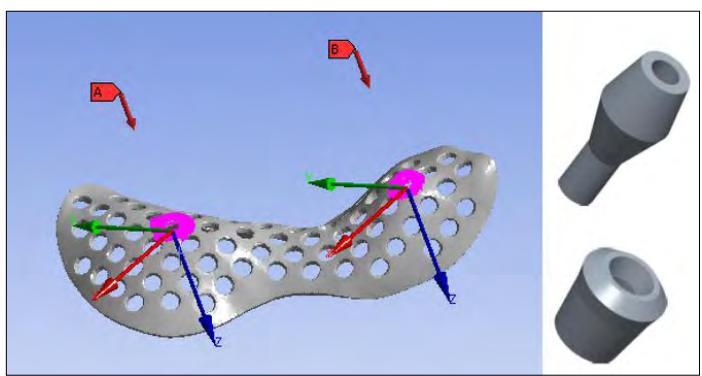

8. ábra. Titánhálóra ható erö, abutment és persely

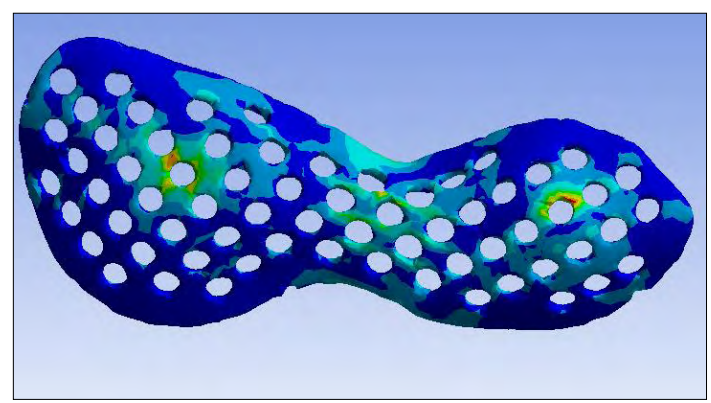

9. ábra. Titánháló feszültsége 
fogmű kerül. Kisebb feszültség fog ébredni a háló szükített területén is.

A 10. ábrán látható a titánháló alakváltozásmértéke. Az erőt az irodalomnak megfelelően határoztam meg. A rágóerő nem függőlegesen hat a fogműre, hanem bizonyos szögben, mellyel szintén több irodalom, tanulmány foglalkozott. A ferde hatásvonalú rágóerőnek köszönhető az effajta alakváltozás, melynek mértéke nagyon minimális.

Az egyéni implantátum gyártását követően mütétre került sor. A 11. ábrán láthatók a műtéti képek, dr. Friedreich Géza Budapesten sikeresen végezte el a mütétet.

Az egyéni implantátumokon elhorgonyzott, virtuálisan tervezett, végleges rögzített fogmű a páciens szájában látható a 12 . ábrán.

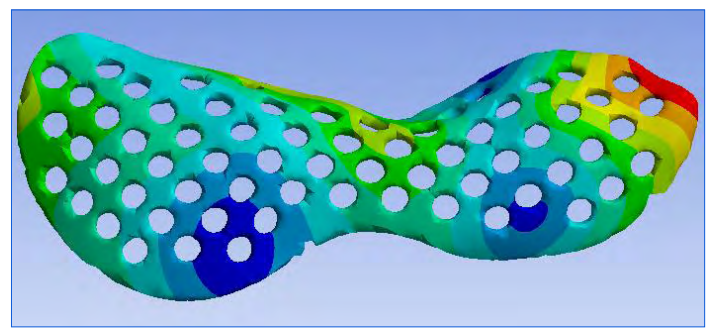

10. ábra. Titánháló-alakváltozás mértéke

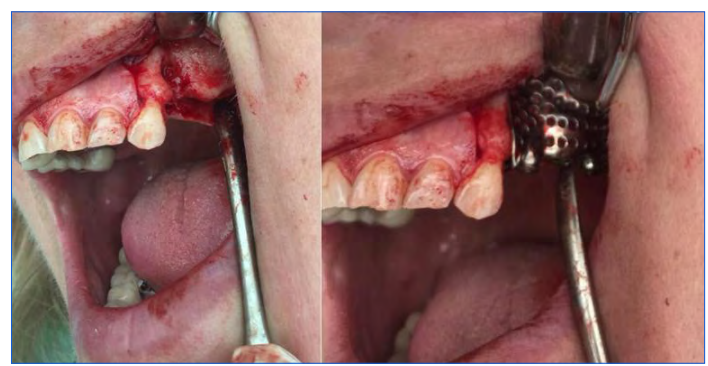

11 ábra. Titánháló behelyezése a páciensbe

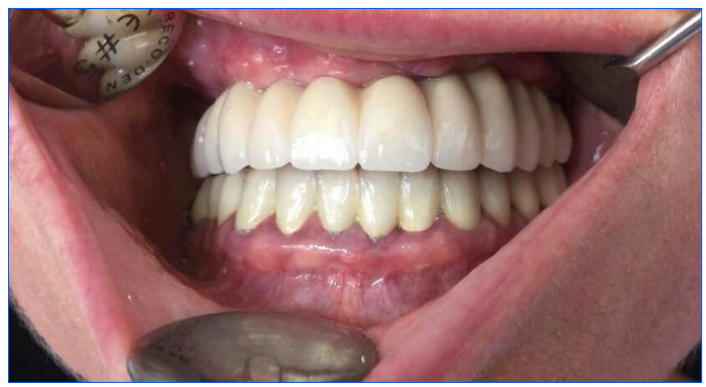

12. ábra. Végleges rögzített fogmü

\section{5. Összegzés}

Az általunk kidolgozott eljárásnak megfelelően lehetőség nyílik az elveszett keményszövetek pótlása nélkül saját fogazathoz mind esztétikailag, mind funkcionálisan nagymértékben hasonló fogpótlás kialakítására, a páciens szájában hoszszú és kockázatos műtétsorozatok nélkül.

\section{Köszönetnyilvánítás}

Köszönetet szeretnénk mondani dr. Friedreich Géza szájsebész-fogorvosnak, aki a mütétet végezte el, Bozsányi Lajos fogtechnikusnak, aki CAD- és individuális csontpótlástervező a Dent-Art-Technik Kft.-nél.

„Nemzetköziesítés, oktatói, kutatói és hallgatói utánpótlás megteremtése, a tudás és technológiai transzfer fejlesztése, mint az intelligens szakosodás eszközei a Széchenyi István Egyetemen.”

\section{Szakirodalmi hivatkozások}

[1] Bergendal T., Engquist B.: Implant-supported overdentures: a longitudinal prospective study. International Journal of Oral and Maxillofacial Implants 13/2. (1998) 253-262.

https://pdfs.semanticscholar.org/51c6/9f4cf669b6d23c30e2f92bca4b81e557e746.pdf

[2] Jingyin L., Shaoxia P., Jing D., Zhongjun M., Yobu F.: Influence of implant number on the biomechanical behvaiour of mandibular implant-retained/ supported overdentures: A three-dimensional finite element analysis. Journal of Dentistry 41/3. (2013) 241-249.

https://doi.org/10.1016/j.jdent.2012.11.008

[3] Lidellow G., Henry P.: The immediately loaded single implant-retained mandibular overdenture: a 36-month prospective study. International Journal of prosthodontics 23/1. (2010) 13-21.

https://pdfs.semanticscholar.org/cb1a/ a1dbff62741d3b98e214adc474d44e3f4494.pdf

[4] Mericske-Stren R. D., Taylor T. D., Belser U.: Management of the edentulous patient. Clinical Oral Implants Research 11. (2000) 108-125.

http://clinicaljude-5thyear.yolasite.com/resources/Management $\% 20$ of $\% 20$ the $\% 20$ edentulous\%20patient\%20Ref1.pdf

[5] Meijer H. J., Raghoebar G. M., Batenburg R. H., Visser A., Vissink A.: Mandibular overdentures supported by two or four endosseous implants: a 10-year clinical trial. Clinical Oral Implants Research, 20/7 (2009) 722-728.

https://doi.org/10.1111/j.1600-0501.2009.01710.x

[6] Weinberger L. A.: The biomechanics of force distribution in implant-supported prostheses. International Journal of Oral and Maxillofacial Implants 17/5 (1993) 19-31. 
[7] Gotfredsen K., Berglundh T., Lindhe J.: Bone reactions adjacent to titanium implants subjected to static load of different duration. Clinical Oral Implants Research, 12/6 (2001) 552-558. https://doi.org/10.1034/j.1600-0501.2001.120602.x

[8] Frost H. M.: Bone „mass” and the „mechanostat”: a prosposal. Anatomical Record 219/1. (1987) 1-9. https://doi.org/10.1002/ar.1092190104

[9] Tepper G., Haas R., Zechner W., Krach W., Watzek G.: Three-dimensional finite element analysis os implant stability in the atrophic posterior maxilla: a mathematical study of the sinus floor augmentation. Clinical Oral Implants Research 13/6. (2002) 657-665.

https://doi.org/10.1034/j.1600-0501.2002.130613.x

[10] Lindhae J., Meyle J., on behalf of Group D of the European Workshop on Periodontology: Peri-implant disease: Consensus Report of the Sixth Europen Workshop on Periodontology. Journal of Clinical Periodontology 35/8. (2008) 282-285. https://doi.org/10.1111/j.1600-051X.2008.01283.x

[11] Renvert S., Quirynen M.: Risk indicators for peri-implantitis. A narrative rewiev. Clinical Oral Implants Research 26/11. (2015) 15-44.

https://doi.org/10.1111/clr.12636

[12] Malevez C., Abarca M., Durdu F., Daelemans P.: Clinical outcome of 103 consecutive zygomatic implants: a 6-48 months follow-up study. Clinical Oral implants Research 15/1. (2004) 18-22. https://doi.org/10.1046/j.1600-0501.2003.00985.x

[13] Neyt L., De Clercq C. A., Abeloos J. V. Mommaerts M. Y.: Reconstruction of the severely resorbed maxilla with a combination of sinus augmentation, onlay bone grafting, and implants. Journal of Oral and Maxillofacial Surgery 55/1. (1997) 1397-1401.

https://doi.org/10.1016/S0278-2391(97)90636-4

[14] Leiser Y., Shilo D., Wolff A., Rachmiel A.: Functional reconstruction in mandibular avulsion injuries. The Journal Craniofacial Surgery, 27/8. (2016) 2113-2116.

[15] LiB.,Zhang L., Sun H., YuanJ., Shen S. G.F., Wang X.: A novel method of computer aided orthognathic surgery using individual $C A D / C A M$ templates: a combination of osteotomy and repositioning quides. British Journal of Oral Maxillofac Surgery 51/8. (2013) 239-244.

https://doi.org/10.1016/j.bjoms.2013.03.007

[16] Rachmiel A., Shilo D., Blanc O., Emodi O.: Reconstruction of complex mandibular defects using integrated dental custom-made titanium implants. British Journal of Oral and Maxillofacial Surgery 55/4. (2017) 425-427.

https://doi.org/10.1016/j.bjoms.2017.01.006

[17] Sing S. L., An J., Yeong W. Y., Wiria F. E.: Laser and Electron-Beam Powder-Bed Additive Manufacturting of Metallic Implants: A review on process, materials and design. Journal of Orthopeadic Research 34/3. (2015) 369-385. https://doi.org/10.1002/jor.23075

[18] Sudarmadji N., Tan J. Y., Leong K. F., Chua C. K., Loh Y. T.: Investigation of the mechanical properties and porosity relationship in selective laser-sintered polyhedral for functionally graded scaffolds. Acta Biomaterialia 7/2. (2011) 530-537. https://doi.org/10.1016/j.actbio.2010.09.024

[19] Yeong W. Y., Sudarmajdi N., Yu H. Y., Leong K. F., Venkatraman S. S., Boey Y. C. F., Tan L. P.: Porous polycaprolactone scaffold for cardiac tissue engineering fabricated by selective laser sintering. Acta Biomaterialia 6/6. (2009) 2028-2034.

https://doi.org/10.1016/j.actbio.2009.12.033

[20] Wiria F. E., Leong K. F, Chua C. K, Liu Y.: Poly-e-caprolactone/hydroxyapatite for tissue engineeringscaffold fabrication via selective laser sintering. Acta Biomaterialia 3/1. (2007) 1-12.

https://doi.org/10.1016/j.actbio.2006.07.008

[21] Yang S. F., Leong K. F., Du Z. H., Chua C. K.: The desing of scaffolds for use in tissue engineering. Part II. Rapid prototyping techniques. Tissue Engineering 8/1. (2002) 1-11.

https://doi.org/10.1089/107632702753503009

[22] Yeong W. Y., Chua C. K., Leong K. F., Chandrasekaran M.: Rapid prototyping in tissue engineering: challenges and potential. Trends in Biotechnology 22/12. (2004) 643-652.

https://doi.org/10.1016/j.tibtech.2004.10.004

[23] Van Noort R.: Titanium: the implant material of today. Journal of Materials Science 22/11. (1987) 3801-3811.

https://doi.org/10.1007/BF01133326

[24] Rack H. J., Quazi J. I.: Titanium alloys for biomedical applications. Materials Science and Engineering 26/8. (2006) 1269-1277.

https://doi.org/10.1016/j.msec.2005.08.032

[25] Long M.; Rack H. J.: Titanium alloys in total joint replecamnet - a materials science perspective. Biomaterials 19/18. (1998) 1621-1639.

https://doi.org/10.1016/S0142-9612(97)00146-4

[26] Cheng A., Humayun A., Cohen D. J., Boyan B. D., Schwartz Z.: Additively manufactured $3 D$ porous Ti-6Al-4V constructs mimic trabecular bone structure and regulate osteoblast proliferation, differentiation and local factor production in a porosity and surface roughness dependent manner. Biofabrication 6/4. (2014) 1-12.

https://doi.org/10.1088/1758-5082/6/4/045007

[27] Zhao G., Zinger O., Schwartz U., Wieland M., Landolt D., Boyan B. D.: Osteobalst-like cells are sensitive to submicron-scale surface structure. Clinical Oral Implant Research 17/3. (2006) 258-264. https://doi.org/10.1111/j.1600-0501.2005.01195.x

[28] Zinger O., Zhao G., Schwartz Z., Simpson J., Landolt D., Boyan B.: Differential regulation of osteoblasts by substrate microstructural features. Biomaterials, 26/14 (2005) 1837-2847.

https://doi.org/10.1016/j.biomaterials.2004.06.035 
[29] Bain C. A., Moy P. K.: The association between the failure of dental implants and cigarette smoking. International Journal of Oral and Maxillofacial Implants 8/6. (1993) 609-615. http://dx.doi.org/10.1097/00008505-199409000-00011

[30] Geng J. P., Tan K. B., Liu G. R.: Application of finite element analysis in implant dentistry: a review of the literature. The Journal of Prosthetic Dentistry, 85/6 (2001) 585-598.

https://doi.org/10.1067/mpr.2001.115251

[31] Rieger M. R., Adams W. K., Kinzel G. L.: A finite element survey of eleven endosseous implants. The Journal of Prosthetic Dentistry 63/4. (1990) 457-465.

https://doi.org/10.1016/0022-3913(90)90238-8

[32] Chun H. J., Cheong J. H., Han J. H., Heo S. J., Chung J. P., Rhyu I. C., Choi Y. C., Baik H. K., Ki Y., Kim M. H.: Evaluation of design parameters of osseointegrated dental implants using finite element analysis. Journal of Oral Rehabilitation, 29/6. (2002) 565-574. https://doi.org/10.1046/j.1365-2842.2002.00891.x

[33] Himmlová L., Dostálová T., Kácovsky A., Konvicková S.: Influence of implant length and diameter on stress distribution: a finite element analysis. The Journal of Prosthetic Dentistry 91/1. (2004) 20-25.

https://doi.org/10.1016/j.prosdent.2003.08.008

[34] Chun H. J., Shin H. S., Han C. G., Lee S. H.: Influence of implant abutment type on stress distribution in bone under various loading conditions using finite element analysis. International Journal of Oral and Maxillofacial Implants 21/2. (2006) 195-202.

https://www.ncbi.nlm.nih.gov/pubmed/16634489

[35] Meijer H. J., Starmans F. J., Steen W. H., Bosman F.: Loading conditions of endosseous implants in an edentulous human mandible: a three-dimensional, finite-element study. Journal of Oral Rehabilitation 23/11. (1996) 757-763.

https://doi.org/10.1046/j.1365-2842.1996.d01185.x

[36] Alkan I., Sertgöz A., Ekici B.: Influence of occlusal forces on stress distribution in preloaded dental implant screws. The Journal of Prosthetic Dentistry 91/4. (2004) 319-325.

https://doi.org/10.1016/j.prosdent.2004.01.016

[37] Kitagawa T., Tanimoto Y., Nemoto K., Aida M.: Influence of cortical bone quality on stress distribution in bone around dental implant. Dental Materials Journal 24/2. (2005) 219-224.

http://dx.doi.org/10.4012/dmj.24.219

[38] Lin C. L., Kuo Y. C., Lin T. S.: Effects of dental implant length and bone quality on biomechanical responses in bone around implants: a 3D non-linear finite element analysis. Biomedical Engineering: Applications, Basis and Communications, 17/1. (2005) 44-49.

https://doi.org/10.4015/S1016237205000081
[39] Saab X. E., Griggs J. A., Powers J. M., Engelmeier R. L.: Effect of abutment angulation on the strain on the bone around an implant in the anterior maxilla: a finite element study. The Journal of Prosthetic Dentistry 97/2. (2007) 85-92.

https://doi.org/10.1016/j.prosdent.2006.12.002

[40] Natali An. N., Pavan P. G., Ruggero A. L.: Evaluation of stress induced in peri-implant bone tissue by misfit in multi-implant prosthesis. Dental Materials 22/4. (2006) 388-395.

https://doi.org/10.1016/j.dental.2005.08.001

[41] Bidez M. W., Misch C. E.: Issues in bone mechanics related to oral implants. Implant Dentistry 1/4. (1992) 15-44.

https://doi.org/10.1097/00008505-199200140-00011

[42] Stegaroiu R., Takahiro S., Haruka K., Osamu M.: Influence of restoration type on stress distribution in bone around implants: a three-dimensional finite element analysis. International Journal of Oral \& Maxillofacial 13/1. (1998) 82-90.

[43] Simon B. R., Woo S. L. Y., Olmstead S. R., McCarty M. P., Jemmott G. F., Akeson W. H.: Evaluation of one-, two-, and three-dimensional finite element and experimental models of internal fixation plates. Journal of Biomechanics 20/2. (1977) 79-86. https://doi.org/10.1016/0021-9290(77)90071-9

[44] Quirynen M., Naert I., Van Steenberghe D.: Fixture design and overload influence marginal bone loss and fixture success in the Brånemark system. Clinical Oral Implants Research 3/3. (1992) 104111.

https://doi.org/10.1034/j.1600-0501.1992.030302.x

[45] Adell R., Lekholm U., Rockler B., Bränemark P. I.: A 15-year study of osseointegrated implants in the treatment of the edentulous jaw. International Journal of Oral Surgery 10/6. (1981) 387-416. https://doi.org/10.1016/S0300-9785(81)80077-4

[46] Meijer H. J. A., Kuiper J. H., Starmans F. J. M, Bosman F.: Stress distribution around dental implants: Influence of superstructure, length of implants and height of mandible. The Journal of Prosthetic Dentistry, 68/1. (1992) 96-102. https://doi.org/10.1016/0022-3913(92)90293-J

[47] Meijer H. J. A., Starmans F. J. M., Steen W. H. A., Bosman F.: Location of implants in the interforaminal region of the mandible and the consequences for the design of the superstructure. Journal of Oral Rehabilitation 21/1. (1994) 47-56.

https://doi.org/10.1111/j.1365-2842.1994. tb01123.x

[48] Wakabayashi N., Ona M., Suzuki T., Igarashi Y.: Nonlinear finite element analyses: Advances and challenges in dental applications. Journal of Dentistry, 36/7 (2008) 463-471.

https://doi.org/10.1016/j.jdent.2008.03.010

[49] Kónya J., Kulcsár K.: Additív technológiával készülő egyéni implantátumok lézeres mikro hegesztésének vizsgálata. Acta Materialia Transylvanica 2/1. (2019) 